Article

\title{
Decoupling of morphological disparity and taxonomic diversity during the end-Permian mass extinction
}

\author{
Junyu Wan (D), William J. Foster, Li Tian, Thomas L. Stubbs (D), Michael J. Benton (D), \\ Xincheng Qiu, and Aihua Yuan (D)
}

\begin{abstract}
An increasing number of unexpectedly diverse benthic communities are being reported from microbially precipitated carbonate facies in shallow-marine platform settings after the end-Permian mass extinction. Ostracoda, which was one of the most diverse and abundant metazoan groups during this interval, recorded its greatest diversity and abundance associated with these facies. Previous studies, however, focused mainly on taxonomic diversity and, therefore, left room for discussion of paleoecological significance. Here, we apply a morphometric method (semilandmarks) to investigate morphological variance through time to better understand the ecological consequences of the end-Permian mass extinction and to examine the hypothesis that microbial mats played a key role in ostracod survival. Our results show that taxonomic diversity and morphological disparity were decoupled during the end-Permian extinction and that morphological disparity declined rapidly at the onset of the end-Permian extinction, even though the high diversity of ostracods initially survived in some places. The decoupled changes in taxonomic diversity and morphological disparity suggest that the latter is a more robust proxy for understanding the ecological impact of the extinction event, and the low morphological disparity of ostracod faunas is a consequence of sustained environmental stress or a delayed post-Permian radiation. Furthermore, the similar morphological disparity of ostracods between microbialite and non-microbialite facies indicates that microbial mats most likely represent a taphonomic window rather than a biological refuge during the end-Permian extinction interval.
\end{abstract}

Junyu Wan* and Aihua Yuan. School of Earth Sciences, China University of Geosciences, Wuhan 430074, China. E-mail: aihuay@qq.com. *Present address: School of Earth Sciences, University College Dublin, Dublin 4, Ireland. E-mail: junyuwan@gmail.com

William J. Foster. School of Earth Sciences, University College Dublin, Dublin 4, Ireland. E-mail: william.foster@ ucd.ie

Li Tian and Xincheng Qiu. State Key Laboratory of Biogeology and Environmental Geology, China University of Geosciences, Wuhan 430074, China. E-mail: tianlibgeg@163.com, qxch0309@163.com

Thomas L. Stubbs and Michael J. Benton. School of Earth Sciences, University of Bristol, Bristol BS8 1TQ, U.K.

E-mail: tom.stubbs@bristol.ac.uk,Mike.Benton@bristol.ac.uk

Accepted: 21 November 2020

Data available from the Dryad Digital Repository: https://doi.org/10.5061/dryad.59zw3r25v

\section{Introduction}

The end-Permian mass extinction was the most catastrophic biotic crisis of the Phanerozoic, with the extinction of more than $80 \%$ of marine invertebrate species (Stanley 2016), and it occurred over a short interval ( $60 \mathrm{kyr})$ that spans the Permian/Triassic boundary (Burgess et al. 2014; Wang et al. 2014). The pattern of extinction is, however, still disputed and often described as a single pulse (Jin et al. 2000), multiple pulses (Song et al. 2013), an extinction interval (Wang et al. 2014), or with long-term environmental deterioration starting before the main extinction pulse (Kiessling et al. 2018). In part, these different interpretations are due to sea-level changes overprinting on our understanding of the timing and pattern of extinction (Yin et al. 2014; Holland and Patzkowsky 2015). In addition to taxonomic losses, the end-Permian extinction recorded widespread ecological disruption and turnover (e.g., Foster and Twitchett 2014; Foster et al. 2018; Song et al. 2018; Martindale et al. 2019). Following the onset of the extinction, there were also sedimentological changes that

(C) The Author(s), 2021. Published by Cambridge University Press on behalf of The Paleontological Society. This is an Open Access article, distributed under the terms of the Creative Commons Attribution licence (http://creativecommons.org/ licenses/by/4.0/), which permits unrestricted re-use, distribution, and reproduction in any medium, provided the original work is properly cited. 
include the widespread occurrence of microbially precipitated carbonates in shallowmarine carbonate settings, for example, calcite crystal fans, microbialites, and oolitic limestones, which have been attributed to reduced skeletal carbonate production and supersaturated conditions (Hips and Haas 2006; Pruss et al. 2006; Friesenbichler et al. 2018; Li et al. 2019; Foster et al. 2020). The formation of these microbially precipitated carbonates is associated with persistent environmental stress during the extinction interval (Clarkson et al. 2015; Li et al. 2015; Foster et al. 2018), but despite this, a relatively high abundance and diversity of ostracods and other metazoans have been reported from these microbially precipitated carbonate facies (Angiolini et al. 2007; Crasquin and Forel 2014; Hautmann et al. 2015; Yang et al. 2015; Foster et al. 2019a; Wan et al. 2019).

Ostracods show a significant turnover due to the end-Permian event, yet a broad range of Permian survivors and newly evolved species dominated a "survival stage" into the earliest Griesbachian and a subsequent "poverty phase" from the Griesbachian Isarcicella staeschei conodont zone into the Dienerian (Crasquin and Forel 2014). Furthermore, the ostracods from the survival stage are typically associated with microbialite facies (Crasquin-Soleau et al. 2004; Forel 2012, 2014; Forel et al. 2013a,b, 2015; Crasquin and Forel 2014; Wan et al. 2019), with only a few exceptions (Foster et al. 2019b; Qiu et al. 2019; Gliwa et al. 2020a, b). The co-occurrence of microbialites and ostracods led Forel et al. (2013b) to suggest that microbial mats provided favorable settings, or refuges, during the extinction interval that could support diverse and abundant ostracod communities.

Ecologically, the ostracod survival stage also records significant decreases in body sizes (i.e., Lilliput effect), precocious sexual dimorphism, and heterochronic growth (deceleration) of ostracods (Forel 2014; Forel et al. 2015). Even if it is unclear which environmental stressor caused these ecological changes (i.e., was it the consequence of high temperatures, deoxygenation of the oceans, changes in nutrient availability, ocean acidification, or a synergistic combination from among these?), ostracod communities do record the ecological implications of the extinction event. The ecological impact of mass extinction events on metazoans can be investigated by studying changes in functional diversity, such as different modes of life (e.g., a combination of tiering, motility, and feeding), which can be recognized typically at the family or superfamily level (Bush and Bambach 2011; Dineen et al. 2014; Foster and Twitchett 2014; Aberhan and Kiessling 2015). However, the methods noted cannot be applied robustly to ostracods during the Permian-Triassic transition, because ostracod assemblages before and after the extinction present the same ecological characteristics and are dominated by deposit-feeding forms, especially the Bairdioidea superfamily (Forel et al. 2009; Forel 2012; Wan et al. 2019). Furthermore, this traditional assertion is currently challenged by the outstanding adaptive potential of the Bairdioidea superfamily (Forel 2014).

An alternative way to study the ecological evolution of metazoan communities is to investigate how mass extinctions and diversification events affected the disparity of metazoan communities. In fact, disparity analyses have been applied widely in ecological diversity and macroevolutionary studies around the endPermian mass extinction, especially for vertebrates, because of their evident functional morphological traits (e.g., Stubbs and Benton 2016; Smithwick and Stubbs 2018). These studies show that when investigating the evolution of metazoans, it is worth considering changes in both taxonomic diversity and morphological disparity, and morphological evolution is tentatively interpreted as having been driven by environmental changes. Although there is limited functional morphological information in the skeletal components of ostracods, several morphometric studies have investigated shape variance in living ostracods and fossil ostracods with distinguishable shell characteristics (Ramos et al. 2016; Martins et al. 2018; Wrozyna et al. 2018). These studies found a close relationship between shell morphology, ontogenetic stage, and the environment. Even for smooth-shelled ostracods, a group that dominates the Permian-Triassic transition, semilandmark and outline methods have been applied successfully to some extant assemblages (Baltanás et al. 2003; Wrozyna et al. 2016; Karanovic et al. 2017). To improve our 
understanding of the ecological consequences of the end-Permian mass extinction and the relationship between the diversity and ecological functioning of ostracod communities, we reexamined morphological disparity and taxonomic diversity of the fossil record of Permian-Triassic ostracods. Further, we investigate whether the taxonomic "microbialite refuge" hypothesis (sensu Gingras et al. 2011; Forel et al. 2013b) allows for greater survival of morphological disparity during the mass extinction interval.

\section{Materials and Methods}

Ostracod Data.--In total, 373 well-preserved specimens of 349 species were selected from published studies with scanning electron microscope images that cover the Permian/Triassic boundary successions and record both microbialites and ostracod assemblages (Fig. 1). The data used in this study, therefore, come from Bálvány-North, Bükk Mountains, Hungary (Forel et al. 2013a); Çürük Dağ, Taurus Mountains, Turkey (Crasquin-Soleau et al. 2004; Forel 2014); Elikah River, central Alborz Mountains, Iran (Forel et al. 2015); Zuodeng, Guangxi, South China (Wan et al. 2019); and Dajiang, Guizhou, South China (Forel 2012).

For the paleoecological analyses, taxonomic diversity is calculated by richness of different

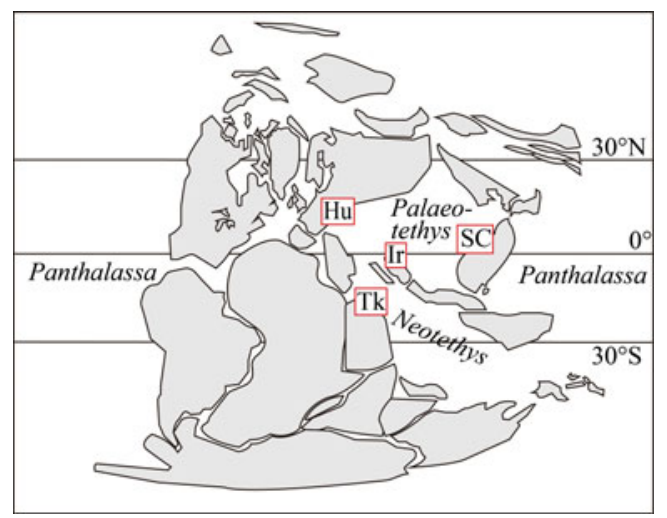

FIGURE 1. Global paleogeographic map of the Permian/ Triassic boundary time interval showing locations of sample sites in this study, based on reconstruction by Golonka (2002). Hu: Bálvány-North, Hungary; Ir: Elikah River, north Iran; SC: Zuodeng and Dajiang, South China; Tk: Çürük Dağ, Turkey. taxa, that is, total numbers of species, genera, and families. Morphological data have been collected from every species with one representative at each section. The valve outline contains primary morphological information for smooth-shelled ostracods, which represent the majority of the Permian-Triassic transition ostracod fauna. The left valve outline in right lateral view was chosen for this study, because for most Permian-Triassic transition ostracods (e.g., Bairdioidea), the left valves overlap the right valves and best represent the overall outline of the carapace. If the right lateral view was not available, the left lateral view was horizontally flipped.

In the morphometric analyses, the ostracods were divided into three time bins: Permian preextinction interval (Pre-E.), extinction interval that spans the Permian/Triassic boundary (Ext.) and Griesbachian postextinction interval (Post-E.). Conodont stratigraphy has been undertaken at all the investigated sections where Hindeodus parvus, whose first appearance datum (FAD) defines the base of the Triassic (Yin et al. 2001), typically occurs near the base of the microbialites facies, and the Isarcicella staeschei biozone occurs above the microbialite interval (Yang et al. 1999; Richoz 2006; Sudar et al. 2008; Jiang et al. 2014; Forel et al. 2015). Furthermore, in most Permian/Triassic boundary successions, the microbialites also have irregular contact with the underlying skeletal packstone, which marks the end-Permian mass extinction horizon (Payne et al. 2007; Chen et al. 2009; Jiang et al. 2014). Some studies recognize the entire microbialite successions as being Triassic due to the isochronism of event deposits and based on biostratigraphic evidence (Jiang et al. 2014; Brosse et al. 2016). In Çürük Dağ, however, Isarcicella isarcica, which marks a later biozone of the Griesbachian, occurs with the FAD of $H$. parous, yet the chemostratigraphy suggests that the microbialites are the same age as those at the other sections (Richoz 2006). Therefore, in our study, these three time bins also correspond to the layers underlying the microbialite interval, the microbialite interval itself, and the layers overlapping the microbialite interval. Both the data before and within the mass extinction interval are available from all the investigated sections, 
which means that changes in morphological disparity as a consequence of the end-Permian mass extinction can be investigated at all the sections. However, after the mass extinction interval, ostracods have only been recorded in the Zuodeng and Çürük Dağ sections. In addition, to investigate the microbialite refuge hypothesis, we subsequently divided the samples from Zuodeng and Çürük Dağ during the extinction interval into microbialite and nonmicrobialite samples, as these different facies were not distinguished at the other sections.

The database of the species and metadata of the ostracod assemblages from each section are available in the Supplementary Table 1, which includes data source, taxon, location, stratigraphic age, and lithology.

Geometric Morphometrics.-Landmark-based geometric morphometrics was used to collect the outline shape data of ostracod valves. The convexity of the valve was not included, as not all publications provided these data for the species investigated here. First, two type III landmarks (LM 1 and 2) were defined by the maximum curvature at the anterior and posterior positions of the valve. Second, two curves, each comprising 15 equidistant semilandmarks, were drawn between LM 1 and LM 2, along the dorsal and ventral borders, respectively (Fig. 2). Both landmarks and semilandmarks were set on images with the program TpsDig v. 2.31 (Rohlf 2015). Third, landmarks were appended to curves, and the sliding directions of the semilandmarks

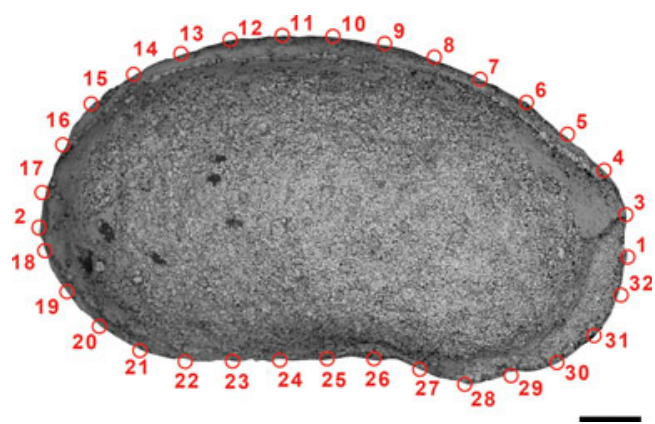

FIGURE 2. An example of the landmark configuration used to investigate changes in morphospace on the left valve outline, in right lateral view, shown using a specimen of Bairdiacypris ottomanensis Crasquin-Soleau et al., 2004 in Wan et al. (2019). Scale bar, $0.1 \mathrm{~mm}$. were determined using TpsUtil v. 1.78 (Rohlf 2015).

A generalized Procrustes analysis (GPA) with a minimized bending algorithm was used to remove the effects of size, location, and orientation of the specimen images using the two-dimensional landmark data, based on the two fixed landmarks and 30 semilandmarks (Gower 1975; Rohlf and Slice 1990). The shape of each specimen was then plotted using the landmark configuration from the GPA.

A principal component analysis (PCA) was carried out on the aligned, post-GPA landmarks to show the morphological variation within each section and between each time interval. In this study, the first three axes explain $\sim 80 \%$ of the morphological variances, and two morphospace plots of PC 1-PC 2 and PC 2-PC 3 were therefore plotted for each section. Shape variation can be distinguished by using thin-plate spline grids and comparing the hypothetical shapes and the mean shape (Claude 2008). The two common disparity statistics - the sum of variances and the volume of morphospace - were both calculated in our study. The former is a measurement of the distances between the points in a morphospace scatter plot and is robust to sample size differences, so it is considered to be the main disparity metric for examining quantitative differences in overall morphological variation between groups herein. But the latter, often correlating strongly with sample size, especially when sample size is small (Ciampaglio et al. 2001), was only used as a subsidiary measure to describe the size of occupied morphospace. A bootstrap analysis (100 replicates with replacement) was applied to most groups for disparity calculation, except the groups without enough data.

All these analyses were conducted in $R$ v. 4.0.0 ( $\mathrm{R}$ Core Team 2020), using the packages geomorph (Adams et al. 2019) and dispRity (Guillerme 2018). In addition, to symmetrically trace the changes of taxonomic diversity and morphological disparity, the log ratios of changes in each measure, including species richness $(\log S)$ and sum of variances $(\log S o V)$, were calculated respectively between different time-bin and lithofacies groups. 
TABLE 1. Results of the principal component (PC) analysis (scores of first three PC axes and shape changes on these three axes). DB, dorsal border; $\mathrm{VB}$, ventral border; $\mathrm{H}_{\max }$, maximum height; $\mathrm{L}_{\max }$, maximum length.

\begin{tabular}{|c|c|c|c|c|c|c|c|}
\hline Section & $\begin{array}{c}\text { PC } 1 \\
(\%)\end{array}$ & $\begin{array}{c}\text { PC } 2 \\
(\%)\end{array}$ & $\begin{array}{c}\text { PC } 3 \\
(\%)\end{array}$ & $\begin{array}{c}\text { Total } \\
(\%)\end{array}$ & $\begin{array}{c}\text { Shape change at } \\
\text { PC } 1\end{array}$ & Shape change at PC 2 & Shape change at PC 3 \\
\hline Zuodeng & 46.9 & 20.1 & 11.5 & 78.5 & $\begin{array}{l}-, \text { elongate } \\
+, \text { stocky }\end{array}$ & $\begin{array}{l}-, \text { DB convex and VB } \\
\text { concave } \\
+, \text { DB straight and VB } \\
\text { convex }\end{array}$ & $\begin{array}{l}-, \mathrm{H}_{\max } \text { close to } \\
\text { posterior } \\
+, \mathrm{H}_{\max } \text { close to } \\
\text { anterior }\end{array}$ \\
\hline Dajiang & 53.6 & 17.8 & 10.0 & 81.4 & $\begin{array}{l}-, \text { elongate } \\
+, \text { stocky }\end{array}$ & $\begin{array}{l}-, \text { DB convex and VB } \\
\text { concave } \\
+, \text { DB straight and VB } \\
\text { convex }\end{array}$ & $\begin{array}{l}-, \mathrm{H}_{\max } \text { close to } \\
\text { anterior } \\
+, \mathrm{H}_{\text {max }} \text { close to } \\
\text { posterior }\end{array}$ \\
\hline Çürük Dag & 41.6 & 25.4 & 9.8 & 76.8 & $\begin{array}{l}\text {-, elongate } \\
+ \text {, stocky }\end{array}$ & $\begin{array}{l}\text {-, DB straight and VB } \\
\text { convex } \\
+, \text { DB convex and VB } \\
\text { concave }\end{array}$ & $\begin{array}{l}-, \mathrm{H}_{\max } \text { close to } \\
\text { posterior } \\
+, \mathrm{H}_{\max } \text { close to } \\
\text { anterior }\end{array}$ \\
\hline $\begin{array}{l}\text { Bálvány } \\
\text { North }\end{array}$ & 47.3 & 22.5 & 12.6 & 82.4 & $\begin{array}{l}-, \text { stocky } \\
+ \text {, elongate }\end{array}$ & $\begin{array}{l}\text {-, DB straight and VB } \\
\text { convex } \\
+, \text { DB convex and VB } \\
\text { concave }\end{array}$ & $\begin{array}{l}-, \mathrm{H}_{\max } \text { close to } \\
\text { posterior } \\
+, \mathrm{H}_{\max } \text { close to } \\
\text { anterior }\end{array}$ \\
\hline Elikah River & 43.4 & 28.2 & 9.7 & 81.3 & $\begin{array}{l}- \text {, elongate } \\
+ \text {, stocky }\end{array}$ & $\begin{array}{l}-, \text { DB convex and VB } \\
\text { concave } \\
+, \text { DB straight and VB } \\
\text { convex }\end{array}$ & $\begin{array}{l}-, \mathrm{L}_{\max } \text { higher } \\
+, \mathrm{L}_{\max } \text { lower }\end{array}$ \\
\hline All sections & 43.6 & 24.2 & 11.0 & 78.8 & $\begin{array}{l}-, \text { stocky } \\
+ \text {, elongate }\end{array}$ & $\begin{array}{l}\text {-, DB straight and VB } \\
\text { convex } \\
+, \text { DB convex and VB } \\
\text { concave }\end{array}$ & $\begin{array}{l}-, \mathrm{H}_{\max } \text { close to } \\
\text { anterior } \\
+, \mathrm{H}_{\text {max }} \text { close to } \\
\text { posterior }\end{array}$ \\
\hline
\end{tabular}

\section{Results}

The results of the PCA maximize and order the interspecific shape differences, and $\sim 80 \%$ of the variance can be explained by the first three principal components (Table 1). Variations along PC 1 correspond to changes in the elongation of the ostracod carapaces, and PC 2 records changes in the convexity of the dorsal and ventral borders. Generally, variance along PC 3 relates to changes in the position of the maximum height of the valve, whereas at the Elikah River section, the variance is explained by the position of the maximum length of the valve. Thin-plate spline grids show mean shapes and hypothetical and practical shapes at the extreme position of each axis (Fig. 3, all five sections; Supplementary Figs. 1-5, Zuodeng, Dajing, Çürük Dağ, Bálvány-North, Elikah River, respectively).

Temporal Variation.-At the Bálvány-North, Dajiang, and Elikah River sections, the volume of morphospace shrinks (Fig. 4), whereas at the Çürük Dağ section, the volume of morphospace remains relatively stable, and in the Zuodeng section, it increases, even though the PCA plot shows the morphospaces to be very similar
(Fig. 5A,B). The impact of the end-Permian mass extinction is shown by a decrease in the sum of variances for all sections except Zuodeng, where it remains constant (Fig. 5A). Generally, the pre-extinction ostracod assemblages show higher morphological disparity by a shift in morphospace occupation because of the presence of some species with extreme shapes that are not recorded from the extinction interval (Fig. 5C). Two declines in morphological disparity occurred with the endPermian mass extinction: the major decline at the onset of the end-Permian extinction, except at Zuodeng, and then a minor one at the end of the extinction interval.

The ostracod assemblages from the Dajiang, Bálvány-North, and Elikah River sections experience declines in $\log S$ by $0.94,0.48$, and $0.73(61 \%, 38 \%$, and $52 \%)$, respectively, through the end-Permian mass extinction interval. These sections record a smaller decrease in $\log$ SoV of ostracod assemblages by $0.56,0.23$, and $0.65(43 \%, 21 \%$, and $48 \%)$, respectively (Table 2, Fig. 6). Therefore, those sections that witnessed taxonomic declines in species richness also recorded associated declines in 


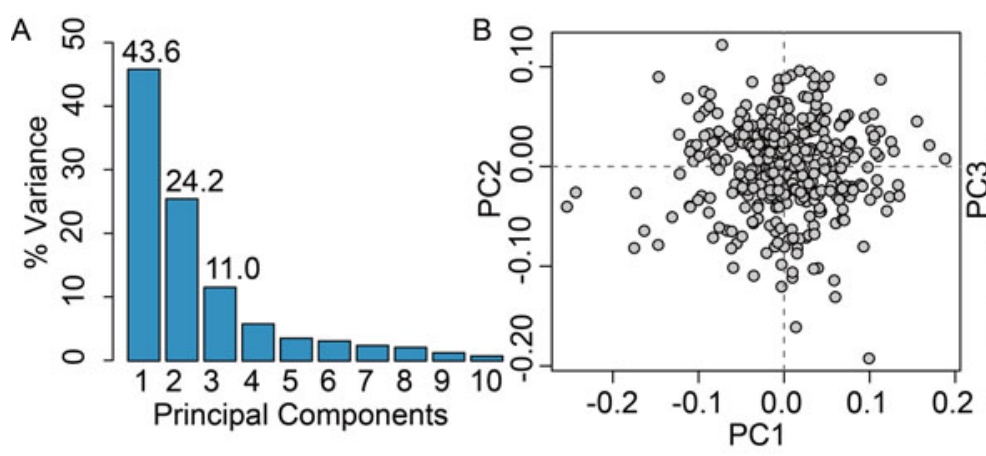

C

Min.
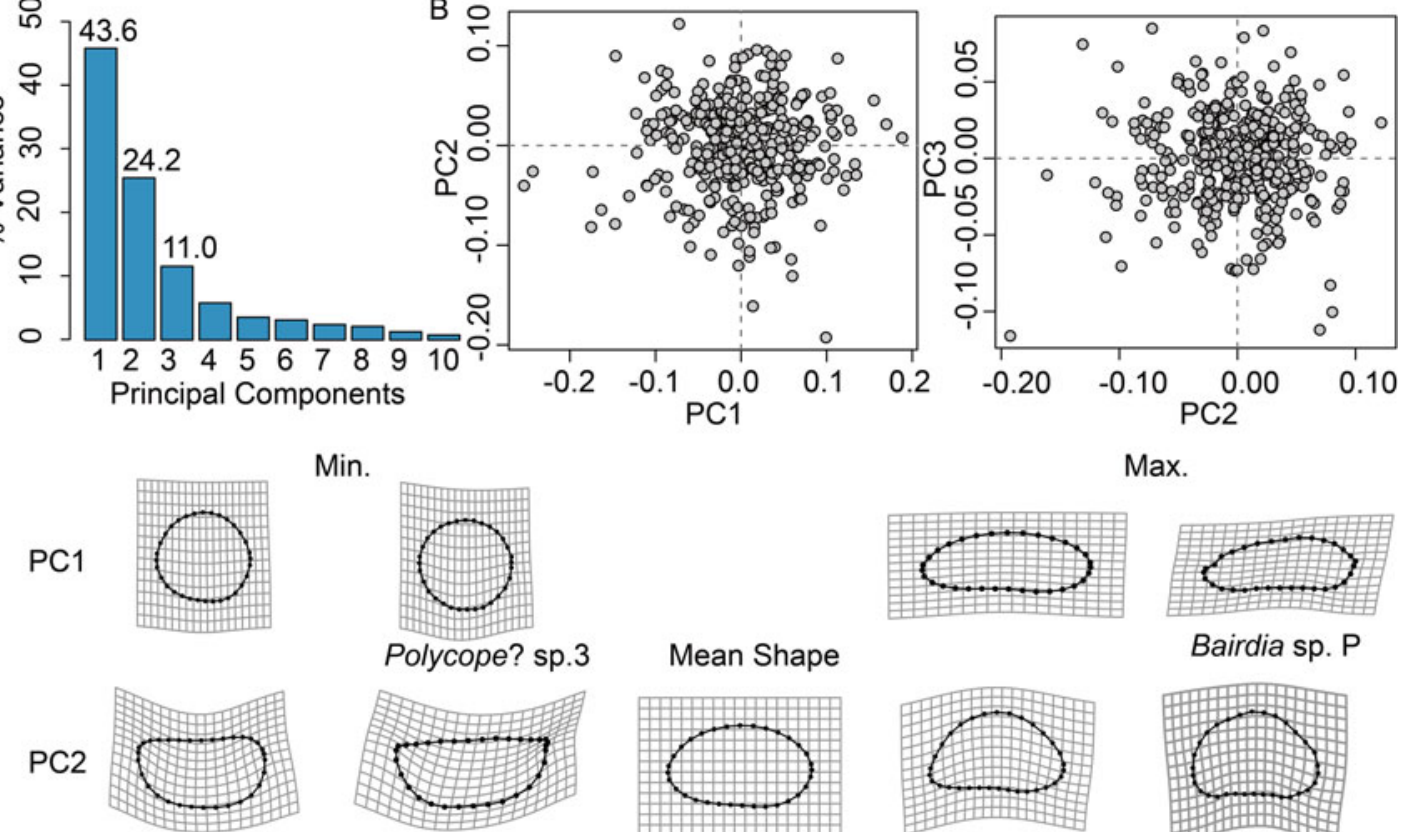

Kirkbya sp. 2
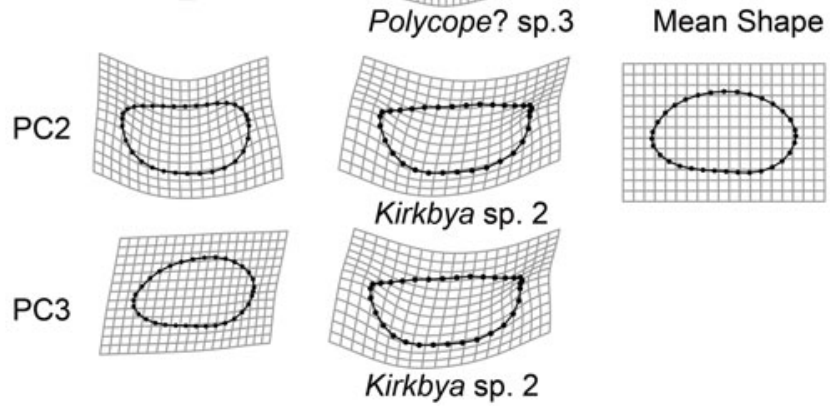

Max.
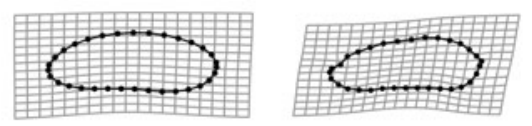

Bairdia sp. P
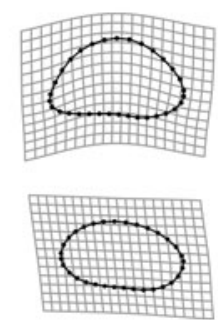

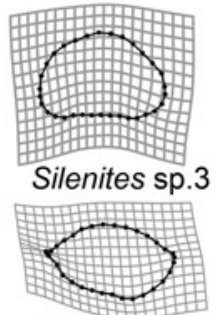

Bairdia sp.33

FIGURE 3. Principal component (PC) analysis results and thin-plate splines of morphological variances of ostracods from all five sections in this study. A, Percentages of the first 10 PC axes; B, scatter plots of PC 1 and PC 2 and PC 2 and PC 3; C, thin-plate splines of mean shape, hypothetical shapes (left), and sample shapes (right) at extreme scores.

morphological disparity. The Zuodeng and Çürük Dağ sections, however, record large increases in $\log S$ associated with the onset of the extinction event by 0.63 and $1.04(88 \%$ and $184 \%$ ), respectively. However, $\log$ SoV records different trends, with only a $0.01(1 \%)$ increase at Zuodeng and a $0.55(42 \%)$ decrease at Çürük Dağ (Table 2, Fig. 6). Furthermore, even when trends are compared between higher taxonomic levels (i.e., at the genus and family levels) and morphological disparity, different rates of changes can be observed (Fig. 6). These results show that variances in morphological disparity and taxonomic richness were decoupled during the end-Permian mass extinction, that is to say, the survivors and newly evolved species during the extinction interval were morphologically similar.

The high number of ostracod species during the extinction interval has been attributed to the presence of microbialites providing a biological refuge (Forel et al. 2013b), and a subsequent decline in ostracod richness is recorded after the extinction interval (Crasquin and Forel 2014). In the Zuodeng section, $\log S$ declines by $3.16(96 \%)$ to only two species, which are insufficient to rigorously investigate the sum of variance. Even so, the two species recovered from the postextinction interval have very different morphologies (Fig. 5A). In Çürük Dağ, there is a $0.69(50 \%)$ decrease in $\log S$, and 27 species are recorded in the postextinction interval (Table 2). This taxonomic decline is also associated with a mere 0.06 (6\%) decline in log SoV (Table 2, Fig. 5B).

Morphological Variation between Facies.-Only at the Zuodeng and Çürük Dağ sections can microbialites or non-microbialite lithofacies be distinguished during the extinction interval (Fig. 7). In the Zuodeng section, the 

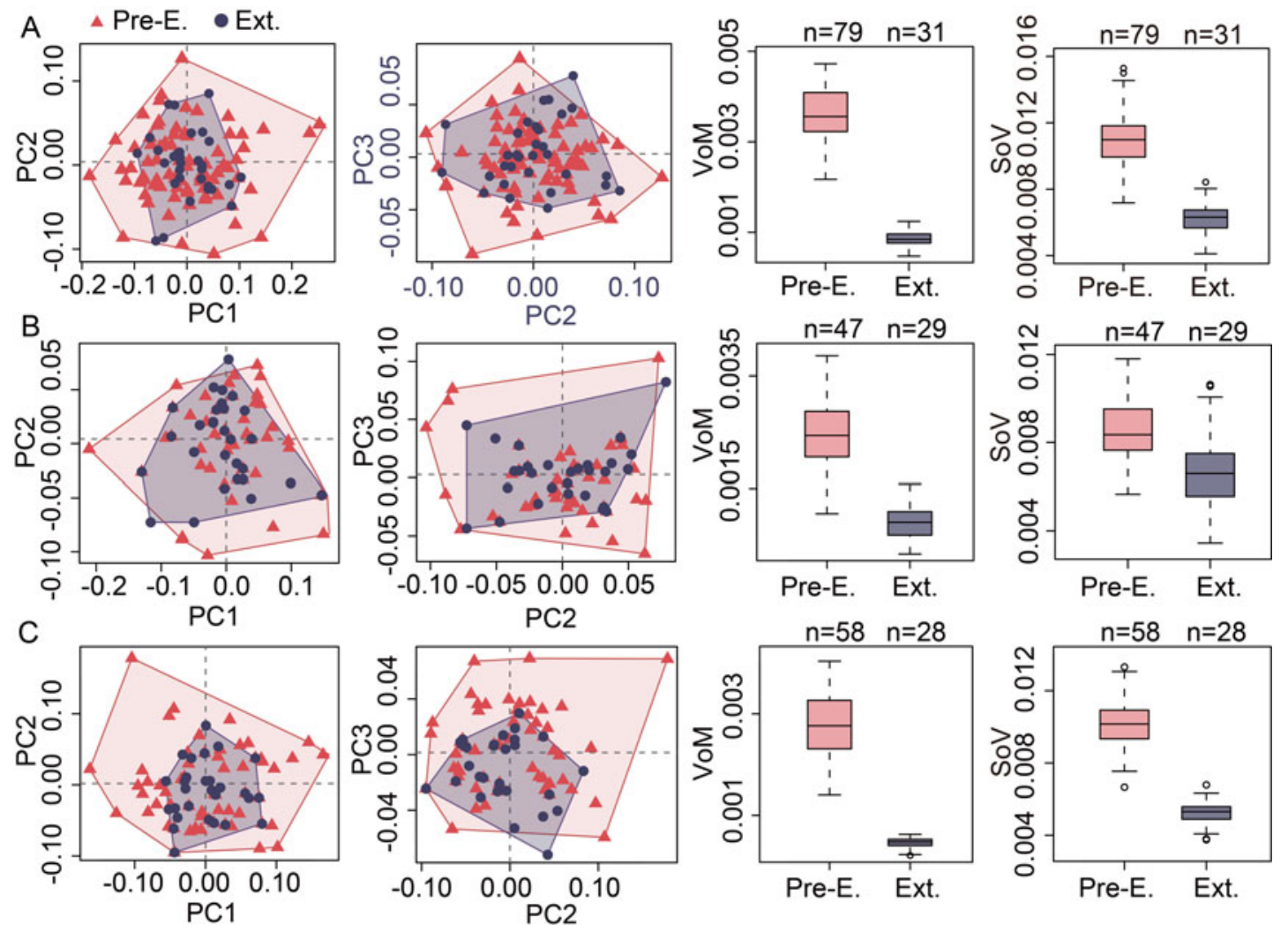

FIGURE 4. Morphospace occupation from the pre-extinction interval (Pre-E.) to the extinction interval (Ext.). A, Dajiang; B, Bálvány-North; C, Elikah River. From left to right for each row, we show scatter plots of principal component (PC) 1 and PC 2 , scatter plots of PC 2 and PC 3, volume of morphospace $(\mathrm{VoM})$, sum of variances $(\mathrm{SoV}) . n=$ number of species in each time bin.

microbialite lithofacies is $0.58(79 \%)$ greater in $\log S$ and has a larger morphospace occupation than the non-microbialite facies based on the presence of some species belonging to Bairdia, Cryptobairdia, Hungarella, Paracypris, and Silenites. However, $\log \mathrm{SoV}$ is only $0.06(6 \%)$ larger in the microbialite facies (Table 2, Fig. 7A). In the Çürük Dağ section, the microbialite lithofacies is $0.19(21 \%)$ greater in $\log S$ than the nonmicrobialite facies, and this is associated with a larger morphospace occupation generated by some species of Bairdia, Bairdiacypris, Bythocypris, and Liuzhinia. But there is only a 0.11 $(11 \%)$ increase in $\log \mathrm{SoV}$ (Table 2, Fig. 7B). Among the species appearing in the morphospace beyond the non-microbialite facies, only one belonging to Bairdiacypris has Paleozoic affinities, but Hungarella, Liuzhinia, and Paracypris show Meso-Cenozoic affinities based on the classification by Crasquin and Forel
(2014). Hungarella and Silenites are genera of Metacopina, which have been considered to be filter-feeding ostracods because the morphology of their hard parts is similar to that of Platycopina (Lethiers and Whatley 1994).

\section{Discussion}

Impact of Sedimentary Facies.-In the uppermost Changhsingian, there is a widespread transient hiatus in shallow-marine successions caused by a regression (Yin et al. 2014) or collapse in carbonate sedimentation (Payne et al. 2007), but the following transgression allows the recurrence of the previous shallow-water deposition in the earliest Triassic (Yin et al. 2014). The samples from the Dajiang, Zuodeng, Çürük Dağ, and Elikah River sections were collected from Changhsingian bioclastic limestones and Griesbachian microbialites, both of 

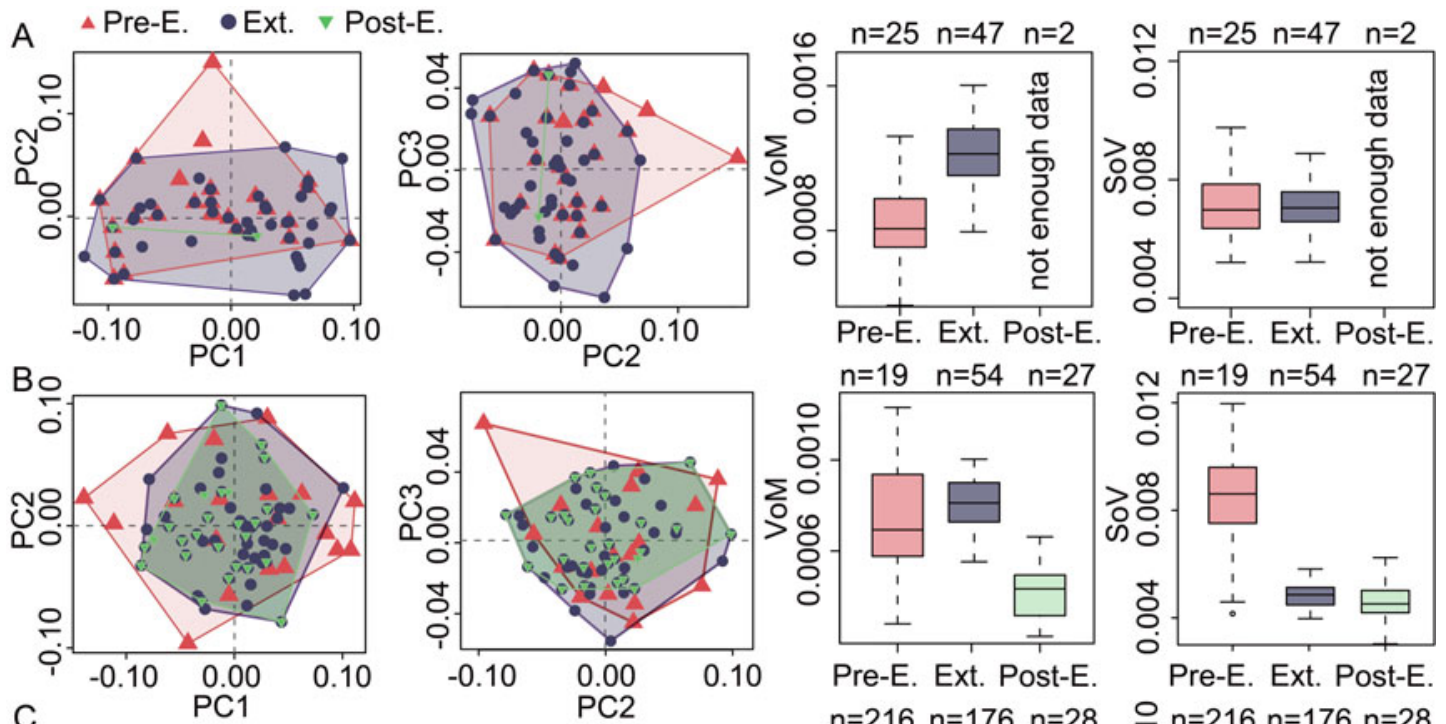

Pre-E. Ext. Post-E.
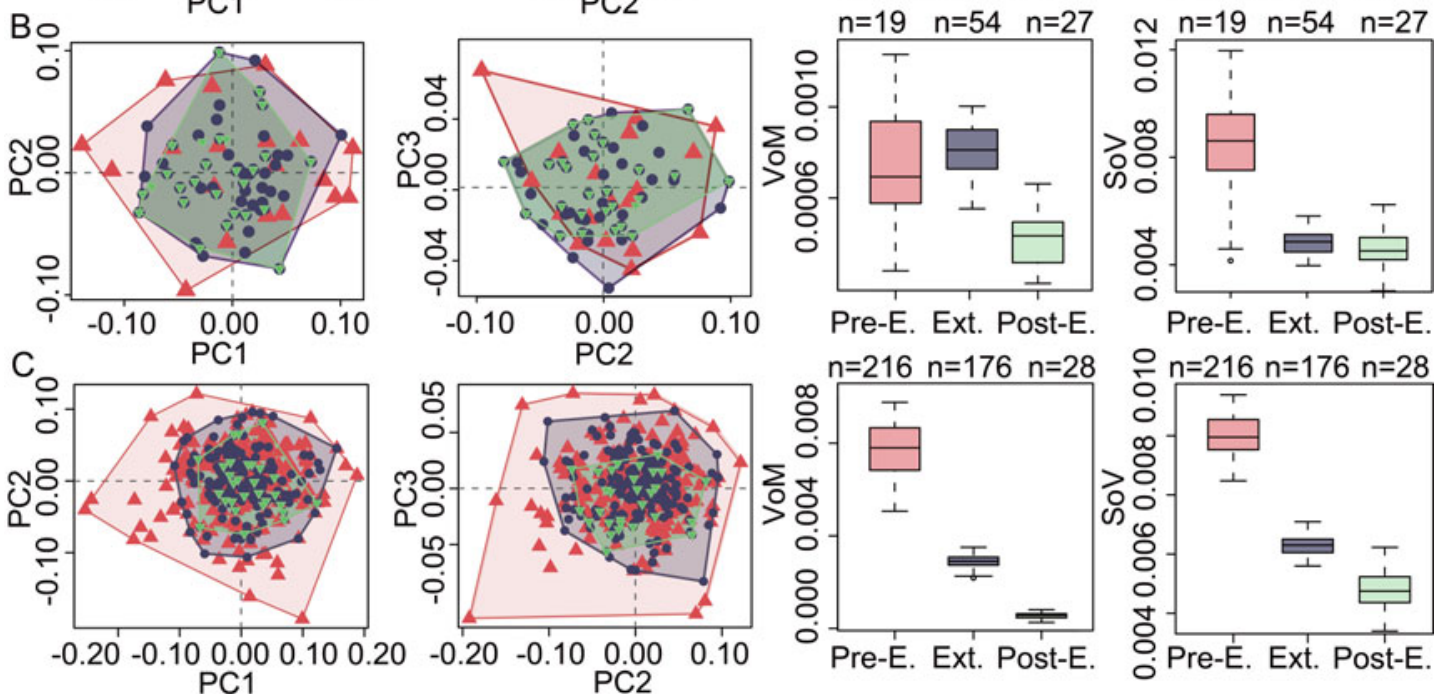

Pre-E. Ext. Post-E.

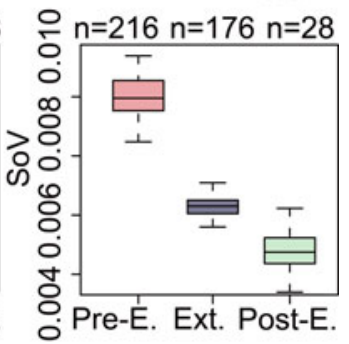

FIGURE 5. Morphospace occupation from the pre-extinction interval (Pre-E.) to the postextinction interval (Post-E.). A, Zuodeng; B, Çürük Dağ; C, all five sections. From left to right for each row, we show scatter plots of principal component (PC) 1 and PC 2, scatter plots of PC 2 and PC 3, volume of morphospace (VoM), sum of variances (SoV). $n=$ number of species in each time bin. Note that when all five sections are combined, the data at the postextinction interval are only available from Zuodeng and Çürük Dağ.

TABLE 2. Log ratios of changes in taxonomic diversity and morphological disparity. VoM, volume of morphospace by PC1 to PC3; SoV, sum of variances. When all five sections are combined, an asterisk $\left(^{*}\right)$ indicates the data at the postextinction interval are only available from Zuodeng and Çürük Dağ. Green indicates a decrease; red indicates an increase.

\begin{tabular}{|c|c|c|c|c|c|c|c|c|c|c|c|}
\hline \multirow{2}{*}{$\frac{\text { Section }}{\text { Dajiang }}$} & \multirow{2}{*}{$\frac{\text { Subsets }}{\text { Pre-extinction }}$} & \multicolumn{2}{|c|}{ Species } & \multicolumn{2}{|c|}{ Genus } & \multicolumn{2}{|c|}{ Family } & \multicolumn{2}{|c|}{ VoM } & \multicolumn{2}{|c|}{ SoV } \\
\hline & & 79 & - & 23 & - & 15 & - & 0.0037 & - & 0.0110 & - \\
\hline & Extinction & 31 & -0.94 & 9 & -0.94 & 7 & -0.76 & 0.0009 & -1.41 & 0.0063 & -0.56 \\
\hline \multirow{2}{*}{ Bálvány North } & Pre-extinction & 47 & - & 15 & - & 9 & - & 0.0024 & - & 0.0083 & - \\
\hline & Extinction & 29 & -0.48 & 13 & -0.14 & 9 & 0 & 0.0009 & -0.98 & 0.0066 & -0.23 \\
\hline \multirow[t]{2}{*}{ Elikah River } & Pre-extinction & 58 & - & 32 & - & 14 & - & 0.0028 & - & 0.0102 & - \\
\hline & Extinction & 28 & -0.73 & 19 & -0.52 & 13 & -0.07 & 0.0005 & -1.72 & 0.0053 & -0.65 \\
\hline \multirow[t]{5}{*}{ Zuodeng } & Pre-extinction & 25 & - & 12 & - & 8 & - & 0.0008 & - & 0.0070 & - \\
\hline & Extinction & 47 & 0.63 & 12 & 0 & 7 & -0.13 & 0.0012 & 0.41 & 0.0071 & 0.01 \\
\hline & Postextinction & 2 & -3.16 & 2 & -1.79 & 2 & -1.25 & - & - & - & - \\
\hline & Non-microbialite & 24 & & 7 & - & 4 & - & 0.0007 & - & 0.0065 & - \\
\hline & Microbialite & 43 & 0.58 & 12 & 0.54 & 7 & 0.56 & 0.0011 & 0.45 & 0.0069 & 0.06 \\
\hline \multirow[t]{5}{*}{ Çürük Dağ } & Pre-extinction & 19 & - & 14 & - & 11 & - & 0.0007 & - & 0.0085 & - \\
\hline & Extinction & 54 & 1.04 & 16 & 0.13 & 10 & -0.10 & 0.0008 & 0.13 & 0.0049 & -0.55 \\
\hline & Postextinction & 27 & -0.69 & 10 & -0.47 & 5 & -0.69 & 0.0004 & -0.69 & 0.0046 & -0.06 \\
\hline & Non-microbialite & 38 & - & 11 & - & 7 & - & 0.0005 & - & 0.0044 & - \\
\hline & Microbialite & 46 & 0.19 & 16 & 0.37 & 10 & 0.36 & 0.0007 & 0.34 & 0.0049 & 0.11 \\
\hline \multirow[t]{3}{*}{ Total } & Pre-extinction & 216 & - & 47 & - & 22 & - & 0.0078 & - & 0.0100 & - \\
\hline & Extinction & 176 & -0.20 & 32 & -0.38 & 16 & -0.32 & 0.0029 & -0.99 & 0.0063 & -0.46 \\
\hline & Postextinction* & 28 & -1.84 & 10 & -1.16 & 5 & -1.16 & 0.0006 & -1.58 & 0.0047 & -0.29 \\
\hline
\end{tabular}




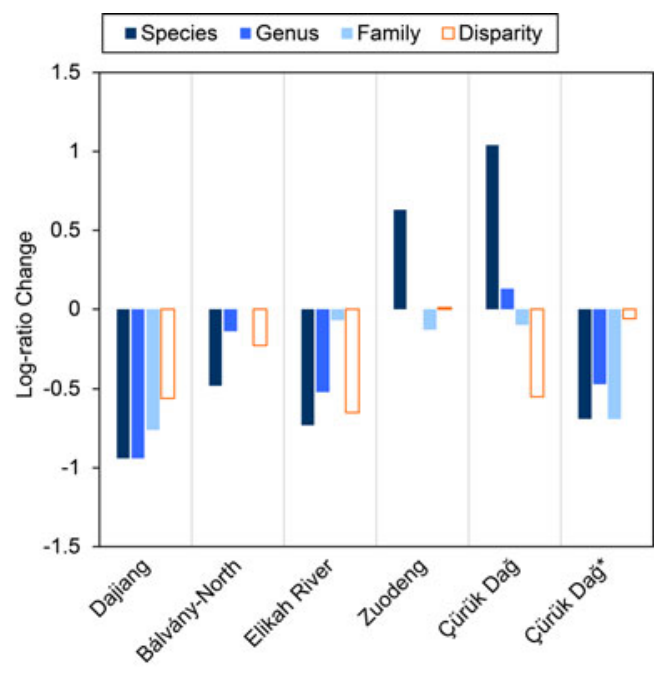

FIGURE 6. Decoupling of log-ratio changes between taxonomic diversity and morphological disparity during the extinction interval. Asterisk $\left({ }^{*}\right)$ marks changes during the postextinction interval.

which were deposited on shallow-marine carbonate platforms between fair and storm weather wave bases (Lehrmann et al. 2005; Gaetani et al. 2009; Kershaw et al. 2012; Fang et al. 2017). The samples from the BálványNorth section come from the Changhsingian
Nagyvisnyó Limestone Formation, which was deposited in an open-marine, homoclinal carbonate ramp below a storm weather wave base, and the Griesbachian Gerennavár Limestone Formation, which also represents deposition on the same sedimentary environment but on a slightly deeper part of the ramp (Hips and Haas 2006). These two formations are also separated by a $<1 \mathrm{~m}$ "boundary shale" that represents the collapse of carbonate sedimentation (Hips and Haas 2006), but no samples from this interval yielded any ostracods (Forel et al. 2013a). In other words, the ostracods in pre-extinction and extinction communities were living in very similar settings. In addition, the impact of the stratigraphic unconformity between the pre-extinction limestones and microbialites, which would artificially condense the last appearance datum to a single horizon (Holland and Patzkowsky 2015), is not expected to be significant, because the stratigraphic gap in the succession is considered to have been brief by geologic standards (sensu Payne et al. 2007; Burgess et al. 2014). But there are changes in the lithofacies as a consequence of the mass extinction event, where habitats previously occupied by metazoan reefs and the presence of a sedimentary
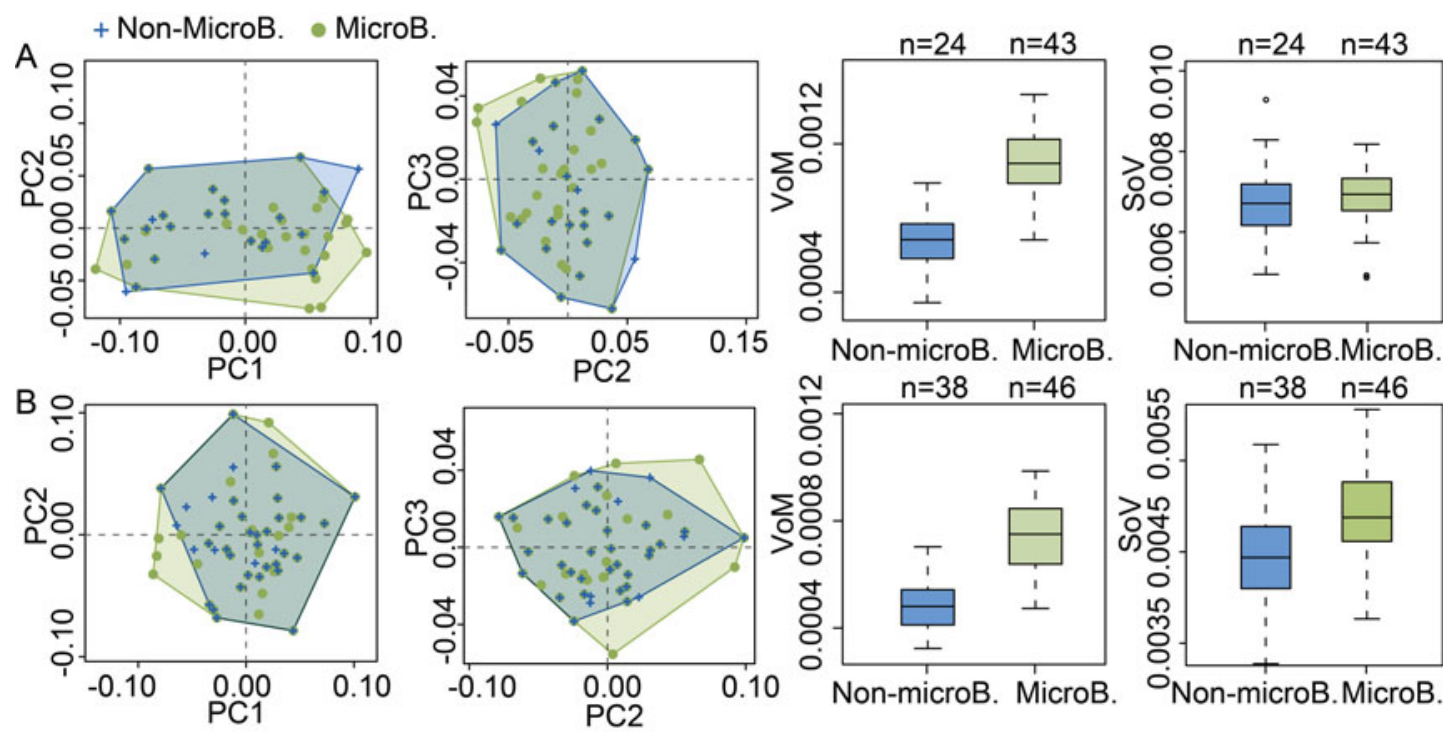

FIgURE 7. Morphospace occupation between microbialites (MicroB.) and non-microbialite (Non-MicroB.) samples from the extinction interval. A, Zuodeng; B, Çürük Dağ. From left to right for each row, we show scatter plots of principal component (PC) 1 and PC 2, scatter plots of PC 2 and PC 3, volume of morphospace (VoM), sum of variances (SoV). $n=$ number of species in each time bin. 
mixed layer are replaced by microbial buildups and undisturbed sediment, respectively, owing to the impact of the extinction on metazoan reef builders and bioturbators (Hofmann et al. 2015; Chen et al. 2019). Facies control on the observed patterns between the pre-extinction and extinction interval is, therefore, interpreted to be minimal.

During the postextinction interval, ostracod faunas enter the "poverty stage" (Crasquin and Forel 2014), so we only have data from the Zuodeng and Çürük Dağ sections. Meanwhile, the termination of these microbialites is the complicated and varied result of global or local rapid changes in water depth (Kershaw et al. 2012), increasing supplies of terrestrial weathered sediments (Bagherpour et al. 2017), and recovery in competition between microbial mats and metazoans (Foster et al. 2020). The overlying Griesbachian mudstone and thinbedded micritic limestone at Zuodeng are interpreted to have been deposited in a deeper part of the platform and with an increasing terrestrial input (Fang et al. 2017). On the other hand, the many oolitic layers with calcilutite interlayers following the microbialites at Çürük Dağ suggest an upward-shallowing sedimentary sequence (Marcoux and Baud 1986). The productive samples here were collected only from mixed carbonate-siliciclastic beds, which were interpreted as having been deposited in a setting similar to that of the underlying microbialites (Forel et al. 2014). Consequently, the simultaneous disappearances of ostracod fauna and microbialites probably indicate rapid facies changes.

Paleoecological Implications of the Mass Extinction.-Ostracods have had a long evolutionary history from the Ordovician to the present day, and study of environmental controls on the morphological dynamics of modern ostracod shell shapes can be informative for understanding fossil examples. Through the end-Permian mass extinction, the most significant impact on morphospace was caused by the disappearance of some key species of the genera Polycope, Paraparchites, Samarella, and other Paleozoic forms (Fig. 3). Polycope is an extant genus that today prefers temperate climates (Kornicker 1959), so its absence might be the consequence of high temperatures during the Permian-Triassic transition (Sun et al. 2012; Wang et al. 2020). In Paraparchites and Samarella, distinct sexual dimorphism has been observed (Forel et al. 2015), and at that time there might have been some higher extinction risk associated with sexual selection (Martins et al. 2018).

Although 68\% (94/139) of newly evolved species during the mass extinction belong to the well-adapted Bairdioidea superfamily, the increased morphological resemblance between ostracod species from the extinction interval might not only reflect genetic similarity but also convergent evolutionary responses to environmental pressures (Benson 1981; Baltanás et al. 2003). Therefore, changes in morphological disparity could reflect both environmental drivers of mass extinctions and evolutionary strategies. The decoupling between diversity and disparity is also observed in the adaptive evolution of other invertebrates, such as ammonoids (McGowan 2004; Brosse et al. 2013; Korn et al. 2020) and some vertebrates (Ruta et al. 2013; Benton et al. 2014; Stubbs and Benton 2016). The pattern of ostracod evolution at this time is interpreted as an example of the diversity-first model, as observed for ammonoids (McGowan and Smith 2007; Brosse et al. 2013), which suggests this kind of animal speciates rapidly into vacant niches with little morphological innovation, perhaps because of the absence of competitors. Other groups, such as tetrapods, show a disparity-first model following the acquisition of a key adaptation and expansion into new ecological niches (Benton et al. 2014). Ecological functions, rather than specific diversity, are more important to the resilience and recovery of the ecosystem (Alvarez et al. 2019). Therefore, even though metazoan diversity is higher in microbialite facies, it does not necessarily indicate a healthy ecosystem. Furthermore, coinciding with smaller body sizes of benthic metazoans, prevalence of opportunistic taxa, and the ecological adaptations to environmental stress, a low morphological disparity of ostracods suggests unfavorable environmental conditions in microbialite facies (Foster et al. 2018).

In terms of definition, morphological disparity is clearly different from taxonomic diversity, 
but a link might be expected as the null model. In other words, as species split and diversify, it might be expected that disparity would increase at the same rate, but it is often found that diversity and disparity are decoupled (Foote 1997; Erwin 2007). At the onset of the end-Permian mass extinction, ostracods recorded a species-level extinction intensity of between $74 \%$ and $100 \%$, but nearly the same high species-level renewal rate (between 65\% and $100 \%$ ) in the microbialite sections during the extinction interval, the time that has been called the survival stage of ostracods, as already mentioned (Crasquin and Forel 2014). Even the Zuodeng (South China) and Çürük Dağ (Turkey) sections both record increases in species richness and specimen abundance. These unusual increases in diversity might be a taphonomic overprint caused by changes in the taphonomic pathways rather than an ecological signal, but the sum of variances was not affected strongly, especially for the Çürük Dağ section, just like the other sections with declining diversity, recording a distinct reduction in disparity. The only exception is the Zuodeng section, where almost the same low disparity has been recorded during the preextinction and extinction intervals. The reason for this sole exception might be something about the particular paleogeographic location of this isolated platform or some form of preextinction environmental deterioration (e.g., Kiessling et al. 2018), when the ostracod fauna was dominated by broadly adapted taxa in the latest Permian, but we need more ostracod data from earlier strata to test these ideas. The changes in higher taxa are not as evident as those at the species level, but the taxonomic diversity still represents different rates of change when compared with morphological disparity. The quantitative morphological analysis, therefore, shows a decoupling of morphological disparity and taxonomic richness, which implies that the sum of variances is a more robust proxy of the environmental consequences to ostracod communities than taxonomic diversity.

All our study sections record only a modest decline in the species richness $(0.20 \log$ SoV; $19 \%$ ) but double the level (0.46 log SoV; 37\%) in the sum of variances during the extinction
(Table 2, Fig. 6), which indicates that the initial pulse of the mass extinction had distinct effects on the morphological disparity of ostracods. The ostracod survival stage, therefore, was a time of relatively high taxonomic richness with a minor reduction or even increase seen in some sections and morphologically convergent evolution. Conversely, the second pulse records a great decline in species richness by $1.84 \log S(84 \%)$, but only a much smaller decline in the sum of variances by $0.29 \mathrm{log}$ SoV $(25 \%)$ in the postextinction interval (Table 2, Fig. 6). Although this second extinction pulse supports the two-pulse extinction pattern (Song et al. 2013), it is probably the result of small sample sizes in the postextinction interval associated with rapid facies changes in the investigated sections. On the other hand, the sum of variances is robust to sample size, especially in the Çürük Dağ section, which has sufficiently abundant data from the postextinction interval. Therefore, the major loss of morphological disparity has been recorded at the onset of the extinction interval or maybe earlier in some places, and the low disparity continues into the postextinction interval. In other words, the ecosystem was more likely to have been catastrophically devastated during the initial pulse of the endPermian extinction in the latest Permian, and then experienced a delayed radiation due to persistent environmental stress.

Implications for the Microbialite-Refuge Hypothesis.-Microbial mat refugia were suggested to have played a critical role in the evolution of life during the Ediacaran, in that they provided oxygenated oases in otherwise anoxic environments and would have been a source of nutrients for grazing metazoans (Gingras et al. 2011; Ding et al. 2019). This concept has also been applied to ostracod faunas from the end-Permian mass extinction interval to explain their unusually high diversity and abundance, as well as the survival of other metazoans in microbialite successions (Forel et al. 2013b, 2015; Crasquin and Forel 2014; Forel 2014). Based on our morphological results, only $11 \%$ of the genera that expanded morphospace occupation in microbialite facies actually have Paleozoic affinities, which contrasts with the fact that $40 \%$ to $67 \%$ of genera 
in all ostracod faunas of the Griesbachian have Paleozoic affinities (Crasquin and Forel 2014; Wan et al. 2019). This heterogeneous composition suggests that Paleozoic survivors were less adapted to the changed environment represented by the microbial mats, but the Mesozoic pioneers, especially some filterfeeding ostracods belonging to Metacopina (i.e., Hungeralla and Silenites), were opportunists that evolved under reduced competitive pressure (Boomer et al. 2008; Forel et al. 2011).

The sum of variances shows no such obvious differentiation in taxonomic diversity between microbialite and non-microbialite facies (Table 2, Fig. 7), which challenges the idea that microbial mats provided a biological refuge. Not only that, the filter-feeding ostracods, occupying a larger morphospace in the microbialite facies, preferred oligotrophic conditions (Forel et al. 2011; Horne et al. 2011), which is inconsistent with the eutrophic conditions during the extinction interval (Schobben et al. 2016). Even for the deposit-feeding ostracods, there are no grazing traces, such as Lamonte trevallis (O'Neil et al. 2020), recorded in the microbialites (Forel et al. 2013b; Qiu et al. 2019). Therefore, the view that microbial mats served as a food source for ostracods is still equivocal, and more supporting evidence is required. Furthermore, a cyanobacteria-dominated microbial mat would be anoxic or euxinic below the surface, which is not an ideal environment for ostracods. Unlike the Ediacaran biota, which had some special adaptive abilities to withstand regular exposure to anoxia and daily cycles in oxygen production (Gingras et al. 2011; Ding et al. 2019), ostracods did not have the same adaptive capabilities. In addition, in modern thrombolites, metazoans that are well adapted to microbial habitats are typically motile and move around the surface of microbial mats to exploit spatial variance in oxygen availability (Tarhan et al. 2013). Because ostracods are also motile, they might be capable of the same adaptation to the microbial environment. There are further aspects of an ostracod's life cycle and behavior that indicate ostracods are not adapted to living within a microbial mat; for example, most ostracods reproduce sexually, rather than by parthenogenesis (Cohen and Morin 1990).
In fact, the idea that microbial mats provided refugia during the end-Permian mass extinction has already been challenged for some metazoan groups. Hautmann et al. (2015) observed that the bivalve and gastropod species found in microbialites did not differ from those in non-microbialite facies, and therefore, microbial mats cannot truly be considered as refugia. Likewise, relatively diverse, postextinction metazoan communities have been reported from non-microbialite successions (Twitchett et al. 2004; Beatty et al. 2008), including ostracod assemblages from South China and Iran (Qiu et al. 2019; Gliwa et al. 2020a,b). Further, the anoxic-dysoxic signal associated with microbialite successions has been reinterpreted to represent reducing conditions within the sediment rather than in the water column (Heindel et al. 2018; Kershaw et al. 2018), which remained well mixed and oxygenated by wave-induced currents in shallow-marine settings (Tang et al. 2017; Heindel et al. 2018).

An alternative explanation for the higher taxonomic diversity and morphological disparity in microbialite facies is that microbial mats were taphonomic windows (Hautmann et al. 2011; Foster et al. 2019b). This idea is supported by investigations on the spatial distribution of benthic fossils between microbialite and non-microbialite fabrics (Hautmann et al. 2015; Foster et al. 2019b, 2020; Suarez-Gonzalez et al. 2019), which suggest that the paraautochthonous metazoans were transported by episodic currents from near the microbial mats into the microbial framework, which provided a site of preferential preservationnamely, a taphonomic window. This idea can also explain the exceptional preservation of Lagerstätten through the Ediacaran and Phanerozoic, where abundant microbes, microbial mats, and microbial films have been identified as being essential for the exceptional preservation of soft tissues, articulated specimens, and trace fossils (Briggs and Wilby 1996; Gall 2001; $\mathrm{Hu}$ et al. 2010; Buatois and Mángano 2011). One further issue is that the high degree of recrystallization and dolomitization associated with Permian/Triassic boundary microbialites would degrade fossil preservation. Nevertheless, micritic envelopes around fossils within microbialites have not only enabled 
enhanced preservation of the fossils but also made it easier to recover a diverse fauna through careful preparation of the samples (Hautmann et al. 2015; Foster et al. 2018).

For all these reasons, we argue that microbial mats might simply have enhanced fossil preservation, rather than providing an essential oxygen and food source for benthic metazoans like ostracods.

\section{Conclusion}

Our study reexamined the fossil record of ostracod communities that span the Permian/ Triassic boundary in order to investigate the ecological consequences of the end-Permian mass extinction. Morphological disparity was generally decoupled from taxonomic diversity, and the major decline at the onset of the extinction interval in most sections suggests that the major ecological changes occurred during the initial pulse of the mass extinction. After that, the sustained low morphological disparity of ostracod faunas, combined with other ecological changes observed in benthic communities across the Permian/Triassic boundary, indicates persistent environmental stress and delayed postextinction radiation. Further, we confirm that occupation of morphospace is greater in microbialites than in nonmicrobialite facies, but these differences in disparity are small, which suggests that microbial mats were favorable for the preservation of diverse ostracods, acting as a taphonomic window instead of refugia during the end-Permian mass extinction.

\section{Acknowledgments}

This work was supported by the National Natural Science Foundation of China (grant nos. 42030513, 41730320, 41661134047, 40902002) and the 111 project from National Bureau of Foreign Experts and Ministry of Education of China (grant no. BP0820004). M.J.B. and T.L.S. were funded by the Natural Environment Research Council (grant no. NE/ P013724/1) and European Research Council (grant no. 788203). W.J.F. was supported in part by a research grant from Science Foundation Ireland (grant no. 13/RC/2092) and is cofunded under the European Regional Development Fund and by iCRAG industry partners. J.W. was funded under the short-term overseas program by School of Earth Sciences, China University of Geosciences (Wuhan), and would like to thank P. Orr for facilitating this research at the University College Dublin. We would also like to thank W. Kiessling and three anonymous reviewers for constructive comments that greatly improved the article.

\section{Literature Cited}

Aberhan, M., and W. Kiessling. 2015. Persistent ecological shifts in marine molluscan assemblages across the end-Cretaceous mass extinction. Proceedings of the National Academy of Sciences USA 112:7207-7212.

Adams, D. C., M. Collyer, and A. Kaliontzopoulou. 2019. Geomorph: software for geometric morphometric analyses, R package version 3.1.0. https://cran.r-project.org/package=geomorph, accessed 25 November 2019.

Alvarez, S. A., S. J. Gibbs, P. R. Bown, H. Kim, R. M. Sheward, and A. Ridgwell. 2019. Diversity decoupled from ecosystem function and resilience during mass extinction recovery. Nature 574:242-245.

Angiolini, L., L. Carabelli, A. Nicora, S. Crasquin-Soleau, J. Marcoux, and R. Rettori. 2007. Brachiopods and other fossils from the Permo-Triassic boundary beds of the Antalya Nappes (SW Taurus, Turkey). Geobios 40:715-729.

Bagherpour, B., H. Bucher, A. Baud, M. Brosse, T. Vennemann, R. Martini, and K. Guodun. 2017. Onset, development, and cessation of basal Early Triassic microbialites (BETM) in the Nanpanjiang pull-apart Basin, South China Block. Gondwana Research 44:178-204.

Baltanás, A., W. Brauneis, D. L. Danielopol, and J. Linhart. 2003. Morphometric methods for applied ostracodology: tools for outline analysis of nonmarine ostracodes. The Paleontological Society Papers 9:101-118.

Beatty, T. W., J. P. Zonneveld, and C. M. Henderson. 2008. Anomalously diverse Early Triassic ichnofossil assemblages in northwest Pangea: a case for a shallow-marine habitable zone. Geology 36:771-774.

Benson, R. H. 1981. Form, function, and architecture of ostracode shells. Annual Review of Earth and Planetary Sciences 9:59-80.

Benton, M. J., J. Forth, and M. C. Langer. 2014. Models for the rise of the dinosaurs. Current Biology 24:R87-R95.

Boomer, I., A. Lord, and S. Crasquin. 2008. The extinction of the Metacopina (Ostracoda). Senckenbergiana Lethaea 88:47-53.

Briggs, D. E., and P. R. Wilby. 1996. The role of the calcium carbonate-calcium phosphate switch in the mineralization of softbodied fossils. Journal of the Geological Society 153:665-668.

Brosse, M., A. Brayard, E. Fara, and P. Neige. 2013. Ammonoid recovery after the Permian-Triassic mass extinction: a re-exploration of morphological and phylogenetic diversity patterns. Journal of the Geological Society 170:225-236.

Brosse, M., H. Bucher, and N. Goudemand. 2016. Quantitative biochronology of the Permian-Triassic boundary in South China based on conodont unitary associations. Earth-Science Reviews 155:153-171.

Buatois, L. A., and M. G. Mángano. 2011. The déjà vu effect: recurrent patterns in exploitation of ecospace, establishment of the mixed layer, and distribution of matgrounds. Geology 39:1163-1166. 
Burgess, S. D., S. Bowring, and S. Z. Shen. 2014. High-precision timeline for Earth's most severe extinction. Proceedings of the National Academy of Sciences USA 111:3316-3321.

Bush, A. M., and R. K. Bambach. 2011. Paleoecologic megatrends in marine Metazoa. Annual Review of Earth and Planetary Sciences 39:241-269.

Chen, J., T. W. Beatty, C. M. Henderson, and H. Rowe. 2009. Conodont biostratigraphy across the Permian-Triassic boundary at the Dawen section, Great Bank of Guizhou, Guizhou Province, South China: implications for the Late Permian extinction and correlation with Meishan. Journal of Asian Earth Sciences 36:442-458.

Chen, Z. Q., C. Tu, Y. Pei, J. Ogg, Y. Fang, S. Wu, X. Feng, Y. Huang, Z. Guo, and H. Yang. 2019. Biosedimentological features of major microbe-metazoan transitions (MMTs) from Precambrian to Cenozoic. Earth-Science Reviews 189:21-50.

Ciampaglio, C. N., M. Kemp, and D. W. McShea. 2001. Detecting changes in morphospace occupation patterns in the fossil record: characterization and analysis of measures of disparity. Paleobiology 27:695-715.

Clarkson, M. O., S. A. Kasemann, R. A. Wood, T. M. Lenton, S. J. Daines, S. Richoz, F. Ohnemueller, A. Meixner, S. W. Poulton, and E. T. Tipper. 2015. Ocean acidification and the Permo-Triassic mass extinction. Science 348:229-232.

Claude, J. 2008. Morphometrics with R. Springer, New York, p. 317.

Cohen, A. C., and J. G. Morin. 1990. Patterns of reproduction in Ostracodes: a review. Journal of Crustacean Biology 10:184-212.

Crasquin, S., and M.-B. Forel. 2014. Ostracods (Crustacea) through Permian-Triassic events. Earth-Science Reviews 137:52-64.

Crasquin-Soleau, S., J. Marcoux, L. Angiolini, R. Sylvain, N. Alda, A. Baud, and B. Yann. 2004. A new ostracode fauna from the Permian-Triassic boundary in Turkey (Taurus, Antalya Nappes). Micropaleontology 50:281-295.

Dineen, A. A., M. L. Fraiser, and P. M. Sheehan. 2014. Quantifying functional diversity in pre- and post-extinction paleocommunities: a test of ecological restructuring after the end-Permian mass extinction. Earth-Science Reviews 136:339-349.

Ding, W., L. Dong, Y. Sun, H. Ma, Y. Xu, R. Yang, Y. Peng, C. Zhou, and B. Shen. 2019. Early animal evolution and highly oxygenated seafloor niches hosted by microbial mats. Scientific Reports 9:13628.

Erwin, D. H. 2007. Disparity: morphological pattern and developmental context. Palaeontology 50:57-73.

Fang, Y., Z. Q. Chen, S. Kershaw, H. Yang, and M. Luo. 2017. Permian-Triassic boundary microbialites at Zuodeng Section, Guangxi Province, South China: geobiology and palaeoceanographic implications. Global and Planetary Change 152:115-128.

Foote, M. 1997. The evolution of morphological diversity. Annual Review of Ecology and Systematics 28:129-152.

Forel, M.-B. 2012. Ostracods (Crustacea) associated with microbialites across the Permian-Triassic boundary in Dajiang (Guizhou Province, South China). European Journal of Taxonomy 19:1-34.

Forel, M.-B. 2014. Heterochronic growth of ostracods (Crustacea) from microbial deposits in the aftermath of the end-Permian extinction. Journal of Systematic Palaeontology 13:315-349.

Forel, M.-B., S. Crasquin, S. Kershaw, Q. L. Feng, and P. Y. Collin. 2009. Ostracods (Crustacea) and water oxygenation in the earliest Triassic of South China: implications for oceanic events at the end-Permian mass extinction. Australian Journal of Earth Sciences 56:815-823.

Forel, M.-B., S. Crasquin, T. Bruhwiler, N. Goudemand, H. Bucher, A. Baud, and C. Randon. 2011. Ostracod recovery after PermianTriassic boundary mass-extinction: the south Tibet record. Palaeogeography, Palaeoclimatology, Palaeoecology 308:160-170.

Forel, M.-B., S. Crasquin, K. Hips, S. Kershaw, P. Y. Collin, and J. Haas. 2013a. Biodiversity evolution through the Permian-Triassic boundary event: ostracods from the Bukk Mountains, Hungary. Acta Palaeontologica Polonica 58:195-219.

Forel, M.-B., S. Crasquin, S. Kershaw, and P. Y. Collin. 2013b. In the aftermath of the end-Permian extinction: the microbialite refuge? Terra Nova 25:137-143.

Forel, M.-B., S. Crasquin, A. Chitnarin, L. Angiolini, M. Gaetani, and Y. Wang. 2015. Precocious sexual dimorphism and the Lilliput effect in Neo-Tethyan Ostracoda (Crustacea) through the Permian-Triassic boundary. Palaeontology 58:409-454.

Foster, W. J., and R. J. Twitchett. 2014. Functional diversity of marine ecosystems after the Late Permian mass extinction event. Nature Geoscience 7:233-238.

Foster, W. J., D. J. Lehrmann, M. Yu, L. Ji, and R. C. Martindale. 2018. Persistent environmental stress delayed the recovery of marine communities in the aftermath of the latest Permian mass extinction. Paleoceanography and Paleoclimatology 33:338-353.

Foster, W. J., D. J. Lehrmann, J. A. Hirtz, M. White, M. Yu, J. Li, and R. C. Martindale. 2019a. Early Triassic benthic invertebrates from the Great Bank of Guizhou, South China: systematic palaeontology and palaeobiology. Papers in Palaeontology 5:613-656.

Foster, W. J., D. J. Lehrmann, M. Yu, and R. C. Martindale. 2019b. Facies selectivity of benthic invertebrates in a Permian/Triassic boundary microbialite succession: implications for the "microbialite refuge" hypothesis. Geobiology 17:523-535.

Foster, W. J., K. Heindel, S. Richoz, J. Gliwa, D. J. Lehrmann, A. Baud, T. Kolar-Jurkovsek, D. Aljinovic, B. Jurkovsek, D. Korn, R. C. Martindale, and J. Peckmann. 2020. Suppressed competitive exclusion enabled the proliferation of Permian/Triassic boundary microbialites. Depositional Record 6:62-74.

Friesenbichler, E., S. Richoz, A. Baud, L. Krystyn, L. Sahakyan, S. Vardanyan, J. Peckmann, J. Reitner, and K. Heindel. 2018. Sponge-microbial build-ups from the lowermost Triassic Chanakhchi section in southern Armenia: microfacies and stable carbon isotopes. Palaeogeography, Palaeoclimatology, Palaeoecology 490:653-672.

Gaetani, M., L. Angiolini, K. Ueno, A. Nicora, M. H. Stephenson, D. Sciunnach, R. Rettori, G. D. Price, and J. Sabouri. 2009. Pennsylvanian-Early Triassic stratigraphy in the Alborz Mountains (Iran). Geological Society of London Special Publication 312:79-128.

Gall, J. C. 2001. Role of microbial mats. Palaeobiology 2:280-284.

Gingras, M., J. W. Hagadorn, A. Seilacher, S. V. Lalonde, E. Pecoits, D. Petrash, and K. O. Konhauser. 2011. Possible evolution of mobile animals in association with microbial mats. Nature Geoscience 4:372-375.

Gliwa, J., M. B. Forel, S. Crasquin, A. Ghaderi, D. Korn, and Y. Wang. 2020a. Ostracods from the end-Permian mass extinction in the Aras Valley section (north-west Iran). Papers in Palaeontology. doi: 10.1002/spp2.1330.

Gliwa, J., A. Ghaderi, L. Leda, M. Schobben, S. Tomás, W. J. Foster, M.-B. Forel, N. Ghanizadeh Tabrizi, S. E. Grasby, U. Struck, A. R. Ashouri, and D. Korn. 2020b. Aras Valley (northwest Iran): high-resolution stratigraphy of a continuous central Tethyan Permian-Triassic boundary section. Fossil Record 23:33-69.

Golonka, J. 2002. Plate-tectonic maps of the Phanerozoic. In W. Kiessling, E. Flügel, and J. Golonka, eds. Phanerozoic reef patterns. Society for Sedimentary Geology Special Publication 72:21-75.

Gower, J. C. 1975. Generalized Procrustes analysis. Psychometrika 40:33-51.

Guillerme, T. 2018. dispRity: a modular R package for measuring disparity. Methods in Ecology and Evolution 9:1755-1763.

Hautmann, M., H. Bucher, T. Brühwiler, N. Goudemand, A. Kaim, and A. Nützel. 2011. An unusually diverse mollusc fauna from the earliest Triassic of South China and its implications for benthic recovery after the end-Permian biotic crisis. Geobios 44:71-85.

Hautmann, M., B. Bagherpour, M. Brosse, Å. Frisk, R. Hofmann, A. Baud, A. Nützel, N. Goudemand, and H. Bucher. 2015. 
Competition in slow motion: the unusual case of benthic marine communities in the wake of the end-Permian mass extinction. Palaeontology 58:871-901.

Heindel, K., W. J. Foster, S. Richoz, D. Birgel, V. J. Roden, A. Baud, R. Brandner, L. Krystyn, T. Mohtat, and E. Koşun. 2018. The formation of microbial-metazoan bioherms and biostromes following the latest Permian mass extinction. Gondwana Research 61:187-202.

Hips, K., and J. Haas. 2006. Calcimicrobial stromatolites at the Permian-Triassic boundary in a western Tethyan section, Bukk Mountains, Hungary. Sedimentary Geology 185:239-253.

Hofmann, R., L. A. Buatois, R. B. MacNaughton, and M. G. Mángano. 2015. Loss of the sedimentary mixed layer as a result of the end-Permian extinction. Palaeogeography, Palaeoclimatology, Palaeoecology 428:1-11.

Holland, S. M., and M. E. Patzkowsky. 2015. The stratigraphy of mass extinction. Palaeontology 58:903-924.

Horne, D. J., S. N. Brandão, and I. J. Slipper. 2011. The platycopid signal deciphered: responses of ostracod taxa to environmental change during the Cenomanian-Turonian boundary event (Late Cretaceous) in SE England. Palaeogeography, Palaeoclimatology, Palaeoecology 308:304-312.

Hu, S., M. Zhu, M. Steiner, H. Luo, F. Zhao, and Q. Liu. 2010. Biodiversity and taphonomy of the Early Cambrian Guanshan biota, eastern Yunnan. Science China Earth Sciences 53:1765-1773.

Jiang, H. S., X. L. Lai, Y. D. Sun, P. B. Wignall, J. B. Liu, and C. B. Yan. 2014. Permian-Triassic conodonts from Dajiang (Guizhou, South China) and their implication for the age of microbialite deposition in the aftermath of the End-Permian mass extinction. Journal of Earth Science 25:413-430.

Jin, Y. G., Y. Wang, W. Wang, Q. H. Shang, C. Q. Cao, and D. H. Erwin. 2000. Pattern of marine mass extinction near the Permian-Triassic boundary in South China. Science 289:432-436.

Karanovic, I., V. Lavtizar, and M. Djurakic. 2017. A complete survey of normal pores on a smooth shell ostracod (Crustacea): landmark-based versus outline geometric morphometrics. Journal of Morphology 278:1091-1104.

Kershaw, S., S. Crasquin, Y. Li, P. Y. Collin, M.-B. Forel, X. Mu, A. Baud, Y. Wang, S. Xie, F. Maurer, and L. Guo. 2012. Microbialites and global environmental change across the Permian-Triassic boundary: a synthesis. Geobiology 10:25-47.

Kershaw, S., H. Tang, Y. Li, and L. Guo. 2018. Oxygenation in carbonate microbialites and associated facies after the end-Permian mass extinction: problems and potential solutions. Journal of Palaeogeography 7:32-47.

Kiessling, W., M. Schobben, A. Ghaderi, V. Hairapetian, L. Leda, and D. Korn. 2018. Pre-mass extinction decline of latest Permian ammonoids. Geology 46:283-286.

Korn, D., A. Ghaderi, N. Ghanizadeh Tabrizi, and J. Gliwa. 2020. The morphospace of Late Permian coiled nautiloids. Lethaia 53:154-165.

Kornicker, L. S. 1959. Distribution of the ostracode suborder Cladocopa, and a new species from the Bahamas. Micropaleontology 5:69-75.

Lehrmann, D. J., J. L. Payne, P. Enos, P. Montgomery, J. Wei, Y. Yu, J. Xiao, and M. J. Orchard. 2005. Field Excursion 2: Permian-Triassic boundary and a Lower-Middle Triassic boundary sequence on the Great Bank of Guizhou, Nanpanjiang basin, southern Guizhou Province. Albertiana 33:169-186.

Lethiers, F., and R. Whatley. 1994. The use of Ostracoda to reconstruct the oxygen levels of Late Palaeozoic oceans. Marine Micropaleontology 24:57-69.

Li, F., J. Yan, Z. Q. Chen, J. G. Ogg, L. Tian, D. Korngreen, K. Liu, Z. Ma, and A. D. Woods. 2015. Global oolite deposits across the Permian-Triassic boundary: a synthesis and implications for palaeoceanography immediately after the end-Permian biocrisis. Earth-Science Reviews 149:163-180.
Li, F., Q. Gong, R. V. Burne, H. Tang, C. Su, K. Zeng, Y. Zhang, and X. Tan. 2019. Ooid factories operating under hothouse conditions in the earliest Triassic of South China. Global and Planetary Change 172:336-354.

Marcoux J., and A. Baud. 1986. The Permo-Triassic boundary in the Antalya Nappes (Western Taurides, Turkey). Memorie della Società Geologica Italiana 34:243-252.

Martindale, R. C., W. J. Foster, and F. Velledits. 2019. The survival, recovery, and diversification of metazoan reef ecosystems following the end-Permian mass extinction event. Palaeogeography, Palaeoclimatology, Palaeoecology 513:100-115.

Martins, M. J. F., T. M. Puckett, R. Lockwood, J. P. Swaddle, and G. Hunt. 2018. High male sexual investment as a driver of extinction in fossil ostracods. Nature 556:366-369.

McGowan, A. J. 2004. Ammonoid taxonomic and morphologic recovery patterns after the Permian-Triassic. Geology 32:665668.

McGowan, A. J., and A. B. Smith. 2007. Ammonoids across the Permian/Triassic boundary: a cladistic perspective. Palaeontology 50:573-590.

O'Neil, G. R., L. S. Tackett, and M. Meyer. 2020. Petrographic evidence for Ediacaran microbial mat-targeted behaviors from the great basin, United States. Precambrian Research 345:105768.

Payne, J. L., D. J. Lehrmann, D. Follett, M. Seibel, L. R. Kump, A. Riccardi, D. Altiner, H. Sano, and J. Wei. 2007. Erosional truncation of uppermost Permian shallow-marine carbonates and implications for Permian-Triassic boundary events. Geological Society of America Bulletin 119:771-784.

Pruss, S. B., D. J. Bottjer, F. A. Corsetti, and A. Baud. 2006. A global marine sedimentary response to the end-Permian mass extinction: examples from southern Turkey and the western United States. Earth-Science Reviews 78:193-206.

Qiu, X., L. Tian, K. Wu, M. J. Benton, D. Sun, H. Yang, and J. Tong. 2019. Diverse earliest Triassic ostracod fauna of the non-microbialite-bearing shallow marine carbonates of the Yangou section, South China. Lethaia 52:583-596.

Ramos, L., G. Cusminsky, A. Schwalb, and M. Alperin. 2016. Morphotypes of the lacustrine ostracod Limnocythere rionegroensis Cusminsky \& Whatley from Patagonia, Argentina, shaped by aquatic environments. Hydrobiologia 786:137-148.

R Core Team. 2020. R: a language and environment for statistical computing. R Foundation for Statistical Computing, Vienna, Austria. https://www.r-project.org.

Richoz, S. 2006. Stratigraphie et variations isotopiques du carbone dans le Permien supérieur et le Trias inférieur de quelques localités de la Néotéthys (Turquie, Oman et Iran). Mémoires de Géologie (Lausanne) 46:1-283.

Rohlf, F. J. 2015. The tps series of software. Hystrix-Italian Journal of Mammalogy 26:9-12.

Rohlf, F. J., and D. Slice. 1990. Extensions of the Procrustes method for the optimal superimposition of landmarks. Systematic Biology 39:40-59.

Ruta, M., K. D. Angielczyk, J. Frobisch, and M. J. Benton. 2013. Decoupling of morphological disparity and taxic diversity during the adaptive radiation of anomodont therapsids. Proceedings of the Royal Society of London B 280:20131071.

Schobben, M., A. Stebbins, A. Ghaderi, H. Strauss, D. Korn, and C. Korte. 2016. Eutrophication, microbial-sulfate reduction and mass extinctions. Communicative and Integrative Biology 9: e1115162.

Smithwick, F. M., and T. L. Stubbs. 2018. Phanerozoic survivors: actinopterygian evolution through the Permo-Triassic and Triassic-Jurassic mass extinction events. Evolution 72:348-362.

Song, H., P. B. Wignall, J. Tong, and H. Yin. 2013. Two pulses of extinction during the Permian-Triassic crisis. Nature Geoscience $6: 52-56$. 
Song, H., P. B. Wignall, and A. M. Dunhill. 2018. Decoupled taxonomic and ecological recoveries from the Permo-Triassic extinction. Science Advances 4:eaat5091.

Stanley, S. M. 2016. Estimates of the magnitudes of major marine mass extinctions in earth history. Proceedings of the National Academy of Sciences USA 113:E6325-E6334.

Stubbs, T. L., and M. J. Benton. 2016. Ecomorphological diversifications of Mesozoic marine reptiles: the roles of ecological opportunity and extinction. Paleobiology 42:547-573.

Suarez-Gonzalez, P., M. I. Benito, I. E. Quijada, R. Mas, and S. Campos-Soto. 2019. "Trapping and binding": a review of the factors controlling the development of fossil agglutinated microbialites and their distribution in space and time. Earth-Science Reviews 194:182-215.

Sudar, M., M. C. Perri, and J. Haas. 2008. Conodonts across the Permian-Triassic boundary in the Bükk Mountains (NE Hungary). Geologica Carpathica 59:491-502.

Sun, Y., M. M. Joachimski, P. B. Wignall, C. Yan, Y. Chen, H. Jiang, L. Wang, and X. Lai. 2012. Lethally hot temperatures during the Early Triassic greenhouse. Science 338:366-70.

Tang, H., S. Kershaw, H. Liu, X. Tan, F. Li, G. Hu, C. Huang, L. Wang, C. Lian, and L. Li. 2017. Permian-Triassic boundary microbialites (PTBMs) in southwest China: implications for paleoenvironment reconstruction. Facies 63:2.

Tarhan, L. G., N. J. Planavsky, C. E. Laumer, J. F. Stolz, and R. P. Reid. 2013. Microbial mat controls on infaunal abundance and diversity in modern marine microbialites. Geobiology 11:485- 497.

Twitchett, R. J., L. Krystyn, A. Baud, J. R. Wheeley, and S. Richoz. 2004. Rapid marine recovery after the end-Permian mass-extinction event in the absence of marine anoxia. Geology 32:805-808.

Wan, J., A. Yuan, S. Crasquin, H. Jiang, H. Yang, and X. Hu. 2019. High-resolution variation in ostracod assemblages from microbialites near the Permian-Triassic boundary at Zuodeng,
Guangxi region, South China. Palaeogeography, Palaeoclimatology, Palaeoecology 535:109349.

Wang, W. Q., C. Garbelli, F. F. Zhang, Q. F. Zheng, Y. C. Zhang, D. X. Yuan, Y. K. Shi, B. Chen, and S. Z. Shen. 2020. A high-resolution Middle to Late Permian paleotemperature curve reconstructed using oxygen isotopes of well-preserved brachiopod shells. Earth and Planetary Science Letters 540:116245.

Wang, Y., P. M. Sadler, S. Z. Shen, D. H. Erwin, Y. C. Zhang, X D. Wang, W. Wang, J. L. Crowley, and C. M. Henderson. 2014. Quantifying the process and abruptness of the end-Permian mass extinction. Paleobiology 40:113-129.

Wrozyna, C., T. A. Neubauer, J. Meyer, and W. E. Piller. 2016. Shape variation in neotropical Cytheridella (Ostracoda) using semilandmarks-based geometric morphometrics: a methodological approach and possible biogeographical implications. PLoS ONE 11:e0168438.

Wrozyna, C., J. Meyer, M. Gross, M. I. F. Ramos, and W. E. Piller. 2018. Definition of regional ostracod (Cytheridella) morphotypes by use of landmark-based morphometrics. Freshwater Science 37:573-592.

Yang, H., Z. Q. Chen, and W. Q. Ou. 2015. Microconchids from microbialites near the Permian-Triassic boundary in the Zuodeng Section, Baise Area, Guangxi Zhuang Autonomous Region, South China and their paleoenvironmental implications. Journal of Earth Science 26:157-165.

Yang, S., W. Hao, and X. Wang. 1999. Conodont evolutionary lineages, zonation, and PT boundary beds in Guangxi, China. Biotic and geological developments in the Paleo-Tethys in China. Peking University Press, Beijing, pp. 81-95.

Yin, H., K. Zhang, J. Tong, Z. Yang, and S. Wu. 2001. The global stratotype section and point (GSSP) of the Permian-Triassic boundary. Episodes 24:102-114.

Yin, H., H. Jiang, W. Xia, Q. Feng, N. Zhang, and J. Shen. 2014. The end-Permian regression in South China and its implication on mass extinction. Earth-Science Reviews 137:19-33. 